\title{
Attitudes of High School Students Towards the Teaching Profession in Iraqi Kurdistan
}

\author{
Suleyman CELIK \\ Ishik University \\ Dean of Education Faculty \\ QaziMuhammedstreet \\ 44001, Erbil \\ Iraq
}

\begin{abstract}
The purpose of this study is to describe the factors those influence the high school students' teaching profession career choices and to explore their attitudes, beliefs and opinions towards teaching profession in Kurdistan Region of Iraq (KRI). A mixed-methods approach was applied through the use of a hand out questionnaire survey contained closed ended questions to describe the factors that affect high school students' career choice among 1989 high school students, of which 56 percent $(n=1113)$ female and, 44 percent $(n=876)$ were male students, in 103, public and 22 private schools, followed by a semi structured interviews with the 12 focused group to explore their perceptions, opinions and attitudes towards teaching profession as a career. Theage range of the respondents was between 16-18 years. The participants were from all over the Kurdistan Region of Iraq and mostly they were from middle and low-socio economic status families. This mixed method study lasted for 6 months during the 2016-2017 academic year. It was significantly found that the majority of the participants do not believe that teaching is an attractive job in regards to social status of teaching, salary, stress that comes with the overloaded work, and the fact that teachers and society do not encourage students to be a teacher. Besides, the participants, who believe that teaching career is not satisfactory, agreed that teaching is a sacred profession. High school students' perception towards teaching profession as a career in the Middle East countries remains a relatively unexplored area within existing literature. This study reveals new insights into the career choices of high school students, who are surrounded between the need and expectation of the education field for quality and the pressure of the society for a status.
\end{abstract}

\section{Introduction}

It is undeniable that education has a vital role in the process of the development of a society. Building an appropriate education system for emerging sociopolitical needs of a state would lead the state in a globalized world. Thus, to have a quality education, first there should be quality teachers in the education field. As teaching and teachers are having an important role to prepare students for a future of relentless change and improvement, it is necessary to bring up those teachers who would be models of innovative practices. Therefore, there is a close relationship between the development of society and teaching profession, or choosing teaching profession as a career. Yet, researches show that the teaching profession as a career is not as attractive as its effect on the society (Gough, 1990; Kyriacou \& Coulthard, 2000; Halperin \& Ratteree, 2003; Mutshaeni, Denhere, \& Ravhuhali, 2015)There have been many research studies around the world for the last 20 years regarding the motivational factors of choosing teaching profession as a career (Brown, 1992; Chuene, Lubben, \& Newson, 1999; Kyriacou \& Kobori, 1998) and it was significantly found that parents, teachers, socio-economic status, career counseling, job opportunity and any role model in students' lives were the main factors that effect student's teaching profession career choice (Darren, 2013)

Research studies show that the families and the social environment play an important part in the career aspiration and career choices (Carpenter \& Fleishman, 1987; Hossler \& Stage, 1992; Shumba \& Naong, 2012,). While the students are trying to make their decisions on career choice, they feel the need of psychological support from their parents. Without this support they do not want to pursue to explore the different career opportunities. In his multivariate analysis Yang (1981) found that father's education extended strong influence than the mother's upon the aspirations levels of the students 
A consistently relationship has been found between the family socio economic status and students' career choices (Yang, 1981; Elsworth et al., 1982). In their resaerch, conducted to 1400 teacher candiataes in different Turkish universities Balyer \& Özcan, (2014) found that most of the students come from lower socio-economic families who live in villages and small towns. This result shows that low socio economic status families cannot provide better chances for their students to choose their careers. Thus it can be concluded that teaching is an economically lower-middle class families occupations.

In addition to those findings, Kyriacou \& Coulthard, (2000)indicated some of the reasons for choosing teaching as a career fall into three main areas:(1) altruistic reasons: considering teaching as a worthwhile and blessed, committed, a desire to help to develop the society; (2) intrinsic reasons: these reasons cover aspects of the job activity itself, such as theactivity of teaching children, and an interest in using their subject matter knowledge and expertise; and (3) extrinsic reasons: these reasons cover aspects of the job which are not inherent in thework itself, such as long holidays, level of pay, and status.

Kyriacou \& Coulthard (2000) also argued that the degree of matching between what a person wants from a career and what a particular career offers to the individuals has a vital effect on students' career choices. This expectations and offers changes from person to person. However, it has emerged lately that the teaching profession is featured lowly among the high schools students (Halperin \& Ratteree, 2003; Mutshaeni, Denhere, \& Ravhuhali, 2015; Murnane, Singer, Willett, Kemple, \& Olsen, 1991; Kyriacou \& Coulthard, 2000). The reasons behind the students negative attitudes towards teaching profession were reported such as over workload, less payment, high stress, lack of status in the society and glamour(Gough, 1990; Kyriacou \& Coulthard, 2000).

Those mentioned reasons are alsolying as a barrier in front of being a teaching profession in Kurdistan Region of Iraq (KRI).Iraqi Kurdistan, officially called the Kurdistan Region of Iraq by the Iraqi constitution is an autonomous region located in northern Iraq. It is also referred to as Southern Kurdistan as Kurds generally consider it to be one of the four parts of Greater Kurdistan, which also includes parts of southeastern Turkey (Northern Kurdistan), northern Syria (Rojava or Western Kurdistan), and northwestern Iran (Eastern Kurdistan). Since there hasn't been any research conducted in terms of teaching profession in the region so far, the literature about the topic is very poor. However, the researcher has been working in Iraqi Kurdistan for 11 years and had many observations regarding the education, especially in teaching and learning process. This research has been conducted in Kurdistan in Northern Iraq, because the KRI is the only autonomus government who has their own rules, laws, courts parliament and the other units as any states have. Moreover, it is a developing region and till 2015 , when the ISIS attacked KRI, there were very huge investments especially on the construction area.

The formal Educational Ladder in Iraqi Kurdistan consists of 2 years pre-school education for the 4-5 years age group (not compulsory); 6 years compulsory primary education for 6-11 years; 6 years of secondary education of 2 phases 3 years per phase and higher education of 2-6 years. In each phases of the Education Ladder, the same curriculum is employed in all the schools across the region. The Kurdish education system has a centralized structure to manage the large number of students and limited source of education. After the secondary school the students have to have a state-based exit examination (called 'Nishtimani'" in Kurdish) to pass to the high school. After the Nishtimani examination, according to their scores the students are placed in different types of high schools.

High school education lasts for 3 years (grade 10-12) and graduates of all high school students should take a leave exam, which is also the University Entrance Examination (Wezari) held yearly by the collaboration of Ministry of Higher Education and Ministry of Education. Admission for the Higher Education is based on the composite scores, from the Wezari and high school grade point average. After the results of the wezari announced, students have one month to select their university programs consistent with their examination marks. In addition to academic preparatory, there are also industrial, commercial, arts and agricultural schools, known as Vocational Secondary Education, which consist of the same 3 years duration.

The Kurdistan Region of Iraq is having many obstacles in front of an ordinary education. The growth of the school age children, the increased number of IDP's, internal migration from rural to urban areas, the growing population and decreased economy resources putting unprecedented pressure on the schooling across the country. Moreover, there is a double shifting in the schools in order to accommodate growing pupil numbers.

Nowadays, in Kurdistan Region finding resources of funding for the education is a big problem, but the bigger problem is distribution and allocate of these limited recourses to overcome lack of schools, overloaded classrooms, lack of teachers, low salary payment of the teachers, and inefficient educational technologies. 
In addition to these problems, the prevalence of violence and harassment against students and teachers are other prominent issues of education. Corporal punishment, rotememorization of textbook content, and an unreflective and disengaging curriculum are also very important problems to be solved in the education field. As a result of these obstacles and lack of economy resources teachers and the students are the most negatively effected ones. These negativity of course effect the students decisions while choosing a career during the high school period. While the students deciding their careers, they consider their innate genetics, special abilities and environmental conditions which will provide them a secure and high status job positions( Krumbolt, 1983). Also, Güneyli \& Aslan, (2009) indicated that work environmental insufficient resources effect the undergraduates career choice decisions negatively. Within this perspective of career choice, it is worthy to search what do the high school students think about being a teacher in Iraqi Kurdistan.

This study was grounded in the integrative career-planning model developed by Hansen (Hansen, 1996)- a theory that deals with how multiple interactive life tasks influence the high school students career choices. With the use of the integrative career planning model, it will be possible for students in high schools to extend traditional motivational theories by comparing correlations of social and environmental factors that direct students' career choices. Specific aims of this research study were to investigate the status of the high school students' attitudes towards teaching profession in Kurdistan region and to examine what factors influence the high school students career opportunities. Since this is the first research in its scope in Kurdistan region, the importance of study is undeniable.

\section{Methods}

\section{Study Design}

In this study a descriptive survey method and an interview to the focused group has been conducted to high school students in Erbil, Duhok, Slemani, Halabja and Soran to gather data as it can be used to understand the students' attitudes, beliefs and opinions towards teaching profession as a career.

\section{Sampling}

In this study, potential respondents, chosen randomly, were the 2500 private and public high school students located in different cities of Kurdistan Region of Iraq. Of the 2500 potential respondents, 1989 from 125 private and public high school participants responded correctly to the paper based questionnaire, resulted in a response rate of 79.56 percent, which was a very high rate of participation comparing to the average rate of other conducted surveys. Of the 1989 participants, 56 percent $(n=1113)$ were female and 44 percent $(n=876)$ were male from 103 public and 22 private high schools among whole Kurdistan Region. On average, there were $15.9112^{\text {th }}$ grade students per school responding to this survey correctly from a total of 125 schools in 4 big cities and 47 school districts. In this study, those participants and the schools were chosen randomly because randomly choosing represents the whole population without any bias. The participants'age range was from 16-18 years and the mean age was 17 years. 65.01 percent of the participants $(n=1293)$ from Erbil city,16.59 percent $(n=330)$ from Sulaymaniah and Halabja,11.42 percent $(n=227)$ from Duhok and 6.98 percent $(n=139)$ from Soran city. Since the participants of this research were from different parts of whole Kurdistan Region of Iraq, it gives us a clear idea of Kurdish students' opinions about being a teaching profession. There are many major and minor ethnic groups live here Kurdistan. 97 percent Kurdish $(\mathrm{n}=1929), 1.2$ percent Arab $(\mathrm{n}=24), 1.7$ percent Turkmen $(\mathrm{n}=34)$, and 0.1 percent other students involved in this study. 81.79 percent of the students $(n=1626)$ indicated that their major field of study is in scientific departments and 18.21 percent $(n=363)$ indicate verbal departments. Overall, the sample of this study represented the whole population of the $12^{\text {th }}$ grade students in Iraqi Kurdistan region.

\section{Procedure}

Following approval by the University Council, data from participants were gathered between 1-12 February 2017. The researcher used a self-designed questionnaire of which most of the questions were derived from the work of Mutshaeni, Denhere and Ravhuhali (Mutshaeni, Denhere, \& Ravhuhali, 2015) in English Language medium with a five-point Likert scale and later on he has this questionnaire translated to Arabic, Kurdish, Sorani and Badini, dialects in Kurdish Language. After having been translated, the questionnaire was conducted to 50 university students whose native language was Kurdish and Arabic to check the consistency of the languages in Erbil. In the meantime, the questionnaire was administrated to 50 students in Duhok and Sulaymaniah cities where the dialects are different from each other. Based on the feedback from the pilot study, different experts of these languages checked the validity and corrected some misunderstood questions. 
The final version of the questionnaire was generated including 24 of which 10 items were positive, 13 items were negative and 1 item was just students' choice of teaching branches. Just after all of these processes the General Director of Planning of Ministry of Education approved and this quantitative data collection tool implemented to the 2500 high school students in 125 schools in different cities of Kurdistan Region. In the second phase, a convenience sample of 12 focus group students were chosen purposefully to explore their opinions beliefs and attitudes towards teaching profession through conversations. Smallnumber of general questions was asked to the interviewee towards teaching and teaching professions in Kurdistan and elicits responses from all the individuals in the groups as well as their reactions to what others said. The interview took approximately 30 minutes.

\section{Data Analysis}

Applying a mixed method, using qualitative and quantitative data gathering tools - survey and interview- gives an opportunity to the researcher to acquire and interpret the feeling of participants in their natural settings. The results of he students' attitudes towards the teaching profession survey were analyzed by SPSS 19.0 program in order to determine students' perception towards teaching profession according to different variables such as gender, monetary issue, job satisfaction, and being an unimpressive job in the society. Interviews with the focused group students were transcribed to divide the data into various themes.

\section{Results}

After analyzing the gathered data by SPSS 19.0, the following descriptive statistics results were appeared from the questionnaire responses and focus group interviews. When the overall results are evaluated, it was seen that the high school students showed an expected attitude towards the teaching profession. The survey questions were distributed to measure the students' attitudes towards teaching profession in terms of 'Love", "cohesion" and "value" factors. After analyzing the reliability and variance ratio of the mentioned factors, a relatively meaningful reliability and variance ratio were obtained from the survey result. 9 items were made up the love factor, 7 items were constituted the cohesion factor, and 7 items measured the value factor.

The Survey Items in Table 1

\begin{tabular}{lll}
\hline 1 & Teaching is my career of choice & Love \\
9 & I like teaching profession & Love \\
10 & Although teaching profession has got many problems, I still want to be a teacher & Love \\
11 & I never think to be a teacher & Love \\
13 & Even if the salary of Teaching profession is much enough, I do not want to be a teacher & Love \\
14 & The last profession that I will choose is the Teaching profession. & Love \\
17 & Even if I like working with the children I do not want to become a teacher & Love \\
19 & I would prefer to work in different field rather than being a teacher & Love \\
24 & If I have to, I would like to be a & Love \\
5 & There is over workload in the teaching profession & Cohesion \\
6 & The teaching profession offers a safe working environment & Cohesion \\
7 & A four year duration of teacher training is too long & Cohesion \\
12 & even if I am an unemployed, I do not think to be a teacher & Cohesion \\
15 & even if I choose the work place I do not want to become a teacher & Cohesion \\
16 & even if the holidays are long enough in teaching profession, I do not want to become a teacher. & Cohesion \\
22 & Thinking of being a teacher makes me unhappy & Cohesion \\
2 & Teaching is a status profession & value \\
4 & Teaching is a very stressful profession & value \\
18 & According to me being a teacher is boring & value \\
20 & being a teacher is not for me & value \\
21 & I think that being a teacher is highly spiritual & value \\
23 & I would like to study teaching professional departments at Ishik University & value \\
3 & Teaching offers attractive salary & value \\
8 & Bursaries can make teaching career attractive & value \\
\hline
\end{tabular}

As it is seen in table 1, 23 items were used to measure and understand the $12^{\text {th }}$ grade students' attitudes and perception towards teaching profession in high schools in Kurdistan Region of Iraq. 
Where the teachers and teaching profession is not a very valuable and satisfactory job both in the society and in the minds of families and students. When the results of the survey were examined, it was interestingly recognized that the averages of the Disagree and Agree scale were very close to each other in Love factors. For example, the average result of Disagree and Strongly Disagree scale of the love factor items was: 358 and Agree and Strongly Agree scale was 361. Besides the mean of the Not Sure scale was 484 and it shows that majority of the students like and respecting teaching however, the economical and societal situation of the region does not support the students to be a teacher. Thus the students show different attitudes towards the profession. The results in table 1 shows that majority of the participants cannot decide whether they would choose teaching as profession or not. Although the region has been facing plenty of challenges first of all in economy, economical sources and distribution of these sources and in every other field of society, these results indicate that the students still do not strongly disagree to be a teacher, and still teaching can be a popular choice with $12^{\text {th }}$ grade students if those students' demands are taken into consideration. Considering the current high school students are in between choosing or not choosing teaching as a career within this tip point of negative situations, they can be attracted with a small effort and can be motivated to be a teacher by increasing the salary and decreasing the stress of the job. Another interesting result in this survey is that, the majority of the respondents like teaching profession $(n=$ 912), and again a huge amount of students either do not care or unconscious and do not sure what to answer $(n=318)$ about teaching. At this age period of the adolescences, the youngsters are at the "identity crises" stage of adolescents. Herring (1998)and Gottfredson(1981) claims that high school students show different attitudes and perspectives about their roles as adults and looks for different specific careers as imbued with different amount of status, because status is an important indicator for them while choosing a career. This, many of the students are hesitant to choose or not to choose the teaching profession. As it is seen in the table 1, the respondents agreed 'I like teaching profession' the most. It might be because of as Hall and Langton (Hall \& Langton, 2006) figures out that teachers are considered as highly influential on the society and seen as a sacred duty. Hence, these factors are not convincing those young students to be a teacher. In addition, as Farmer (Farmer, 1995) and McDonald and Jessel (McDonald \& Jessell, 1992) pointed out, young students are often influenced by the stereotypical views of specific careers, which in Kuridtan Region is mostly health professions and civil engineering. Teaching is no longer a high sterotypical status of career. Nonetheless, the averall number of the respondents demonstrated that, besides all its negative circumstances, like and respecting teaching.Table 2also indicates that the respondents think that, teaching profession is not very unbearable but needs to be enhanced in terms of social status, and high salary.

Frequency and Percent distribution of Love Factor in table 2

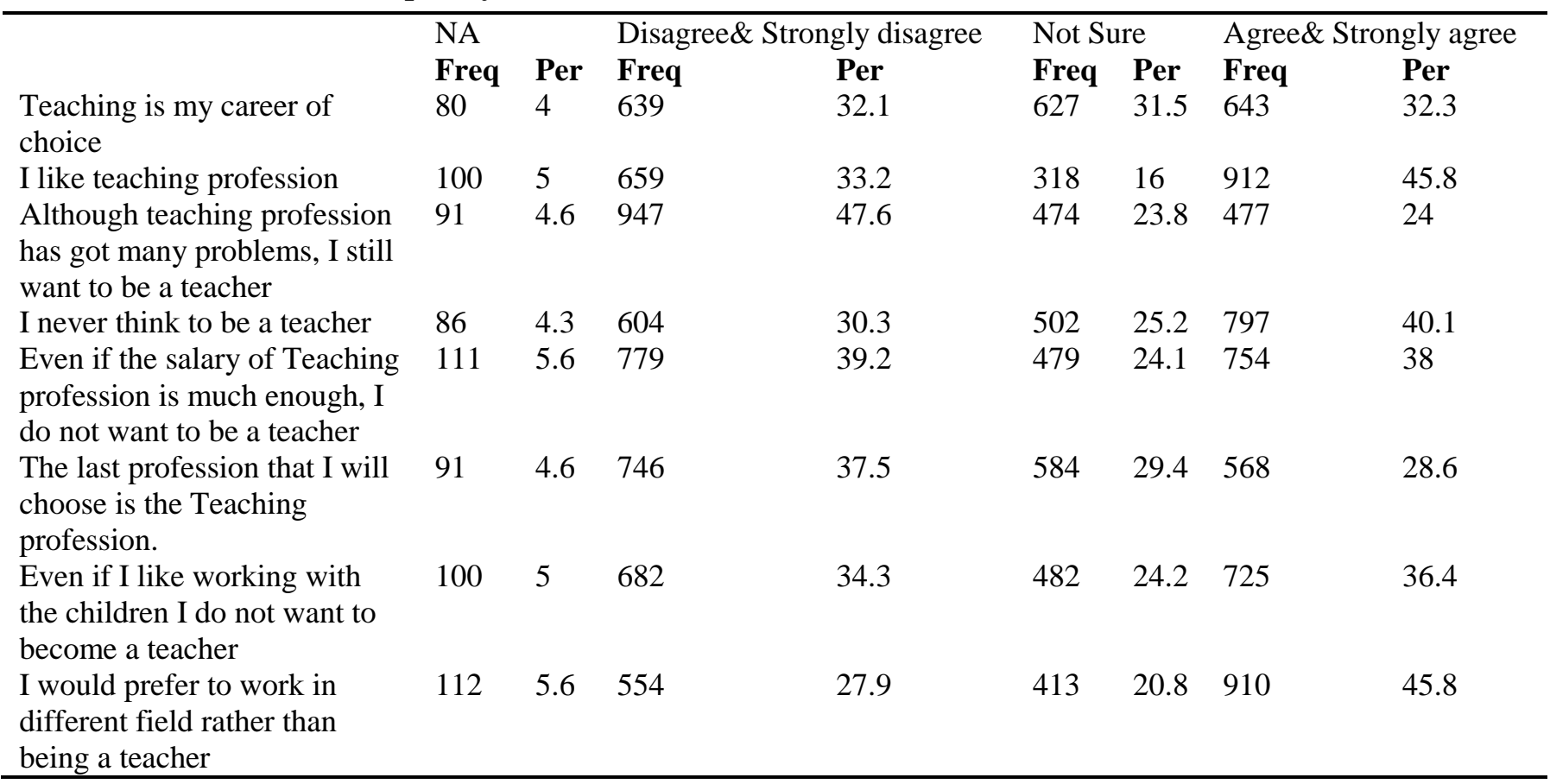


Table 3 demonstrates whether the students and teaching profession is suitable for each other. More than half of the respondents replied that there is a huge workload for the teachers both inside and outside the classroom. This amount of percentage is quite reflects the general idea of the society who likes the holidays and off days very much. On the other hand, those, who think that teaching is an overloaded profession, beleive that schools are one of the safest places in Kurdistan region. The duration of the undergraduate study for being a teacher is quite adequate and not too long. For the high school students having a four-year undergraduate study is to be. Yet, even though they wouldn't have a job, they do not want to be a teacher. Having positive feelings toward teaching, at the same time not want to be teacher seem challenging. Here in Kurdistan region, there is still tribalism and people want to work near their tribes or cities. A student from Slemani wants to work in Slemani or near there and it is not very easy to find every job position in near their cities. In teaching profession, even though they would choose the work place, they do not want to be teachers at all. This survey item is a very strong indicator about their perceptions towards teaching. Because staying with their families is one of the most important life events in this traditional society. In overall distribution, the majority of the respondents do not think that teaching profession is a good choice for them

\section{Frequency and Percent distribution of Cohesion Factor in Table 3}

\begin{tabular}{|c|c|c|c|c|c|c|c|c|}
\hline \multirow[b]{3}{*}{$\begin{array}{l}\text { There is over workload in the teaching } \\
\text { profession }\end{array}$} & \multicolumn{2}{|l|}{ NA } & \multicolumn{2}{|c|}{$\begin{array}{l}\text { Disagree\&Strongly } \\
\text { Disagree }\end{array}$} & \multicolumn{2}{|c|}{ Not Sure } & \multicolumn{2}{|c|}{$\begin{array}{l}\text { Agree\& } \\
\text { Strongly Agree }\end{array}$} \\
\hline & Freq & Per & Freq & Per & Freq & Per & Freq & Per \\
\hline & 82 & 4.1 & 289 & 14.6 & 362 & 18.2 & 289 & 14.6 \\
\hline $\begin{array}{l}\text { The teaching profession offers a safe } \\
\text { working environment }\end{array}$ & 87 & 4.4 & 278 & 14 & 512 & 25.7 & 278 & 14 \\
\hline $\begin{array}{l}\text { A four year duration of teacher training is } \\
\text { too long }\end{array}$ & 87 & 4.4 & 278 & 14 & 512 & 25.7 & 278 & 14 \\
\hline $\begin{array}{l}\text { Even if I am an unemployed, I do not } \\
\text { think to be a teacher }\end{array}$ & 114 & 5.7 & 931 & 46.8 & 500 & 25.1 & 931 & 46.8 \\
\hline $\begin{array}{l}\text { Even if I choose the work place I do not } \\
\text { want to become a teacher }\end{array}$ & 168 & 8.4 & 557 & 28 & 510 & 25.6 & 557 & 28 \\
\hline $\begin{array}{l}\text { Even if the holidays are long enough in } \\
\text { teaching profession, I do not want to } \\
\text { become a teacher. }\end{array}$ & 165 & 8.3 & 671 & 33.7 & 600 & 30.2 & 671 & 33.7 \\
\hline $\begin{array}{l}\text { Thinking of being a teacher makes me } \\
\text { unhappy }\end{array}$ & 111 & 5.6 & 888 & 44.7 & 368 & 18.5 & 888 & 44.7 \\
\hline
\end{tabular}

The students consider the teaching as a status job that can influence the society in the future. In their sincere feelings, the students think of that teaching profession is really important for the future development of the society. The results of the survey item regarding status (82.6\%) show that teaching is a status job. To support this idea, many of the students $(\mathrm{N}=889)$ responded that teaching is not a boring profession. The clearest idea of the students towards teaching profession is in the spirituality item. The respondents $(n=1233)$ agreed that teaching profession is sacred, and a holy duty to bring up a character or to transform the society. Of course those students' ideas were influenced by the Islamic culture and the community sees the teaching as the job of Prophets. On contrary to all these positive ideas, high schools students do not think that the teachers are paid enough. The economical crises, especially after the ISIS attack in 2015, hit the salary payment and the government cannot pay the salaries of the officers regularly since then. Within this context, teachers cannot handle the challenges.

In the previous table, it was indicated that teaching is a very overloaded profession. In other words teachers are overloaded (Chisholm, 1999). The high school students perceived the teaching profession as a stressful job because of much workload. Besides, they estimated the teaching profession not very advantageous in terms of payment and workload. Actually, a huge level of agreement is indicated with respect to the view that teachers are not paid enough. Nearly $44 \%$ of the respondents disagree that the teachers are well paid and $30.5 \%$ are not sure whether they are paid or not. It should be spoken that the respondents hesitate while answering the monetary issues and problem. However, there has been a strike at the schools and the teachers have been protesting the payment and low salary in some parts of Kurdistan Region for nearly 6 months. 
The salary of the teachers is strongly discussed in the open-ended comments, where all the respondents argue about the compensation as a reason not to become a teaching profession as a career. When it is asked the students if the scholarships or bursaries can be a motivational factor to be a teacher, $(n=785) 51 \%$ of them agreed and strongly agreed on this item. The majority of the students were attracted to take up bursaries, or scholarships can motivate them to be teachers.

Frequency and Percent distribution of Value Factor in Table 4

\begin{tabular}{|c|c|c|c|c|c|c|c|c|}
\hline \multirow[b]{4}{*}{$\begin{array}{l}\text { Teaching is a status } \\
\text { profession }\end{array}$} & \multirow{2}{*}{\multicolumn{2}{|c|}{ NA }} & \multicolumn{4}{|c|}{ Disagree } & \multirow{2}{*}{\multicolumn{2}{|c|}{$\begin{array}{l}\text { Agree\& } \\
\text { Strongly } \\
\text { agree }\end{array}$}} \\
\hline & & & \multicolumn{2}{|c|}{$\begin{array}{l}\text { \&Strongly } \\
\text { Disagree }\end{array}$} & \multicolumn{2}{|c|}{ Not Sure } & & \\
\hline & Freq & Per & Freq & Per & Freq & Per & Freq & Per \\
\hline & 69 & 3.5 & 116 & 5.9 & 160 & 8 & 1644 & 82.6 \\
\hline $\begin{array}{l}\text { Teaching is a very } \\
\text { stressful profession }\end{array}$ & 127 & 6.4 & 444 & 22.3 & 602 & 30.3 & 816 & 41 \\
\hline $\begin{array}{l}\text { According to me being } \\
\text { a teacher is boring }\end{array}$ & 128 & 6.4 & 889 & 44.7 & 312 & 15.7 & 660 & 33.2 \\
\hline $\begin{array}{l}\text { Being a teacher is not } \\
\text { for me }\end{array}$ & 97 & 4.9 & 637 & 32 & 477 & 24 & 778 & 39.2 \\
\hline $\begin{array}{l}\text { I think that being a } \\
\text { teacher is highly } \\
\text { spiritual }\end{array}$ & 104 & 5.2 & 250 & 12.5 & 408 & 20.5 & 1227 & 61.7 \\
\hline $\begin{array}{l}\text { Teaching offers } \\
\text { attractive salary }\end{array}$ & 83 & 4.2 & 888 & 44.7 & 608 & 30.6 & 410 & 20.6 \\
\hline $\begin{array}{l}\text { Bursaries can make } \\
\text { teaching career } \\
\text { attractive }\end{array}$ & 170 & 8.5 & 321 & 16.2 & 723 & 36.3 & 775 & 38.9 \\
\hline
\end{tabular}

\section{Data Collection Through Interviews}

After conducting the survey to the $12^{\text {th }}$ grade high school student, an interview was held with the 12 focus groups of students. Each group was consisted of 4 students and those students were chosen purposefully from different cities in Kurdistan. The interview took in a very comfortable atmosphere where the students yield the best information, gave deep information about the teaching profession situation in Kurdistan and reflect their ideas towards it. Because of the group format, those focus group interviews were an efficient means of collecting data. The themes aspiration, and attitudes toward teaching profession, was discussed with those students.

\section{Career aspirations and plans}

Most of the high school students demonstrated that they would like to be medical doctor, dentist, pharmacist or civil engineer regardless of their abilities, and academic sufficiency. None of those studentsconsider their eligibility to study in those departments, nor their GPA's are high enough to go to the universities to study these careers. However, some of the students, who have been counseled and assisted in choosing a career by the college counselors especially in the private schools, mentioned that they are planning to be a teacher in the future. Their decision to become a teacher is not because of their low GPA, it is because of their beliefs, thoughts and notions that education and teachers can solve the obstacles by bringing up a well-educated generation. Also, the students responded that the salary of the teachers is very low and is not paid regularly. Also they suffer humiliation from the society. Being a teacher, in the mind of the society, is the worst decision regarding the career choice and the last option to have as a job. One of the most interesting answers is that the students do not choose their careers according to their strengths and abilities, students' choose their careers according to their GPA. Thus, if a students would study teaching profession, it is not because of s/he likes it, most probably it is because of their GPA allows them to study just teaching profession.

\section{Attitudes toward teaching profession}

During the open-ended question answer sessions, the students showed their attitudes toward the teaching profession. First of all, they said that the schools as a work place were very uncomfortable. The school buildings were very old and the teaching materials were lack and the existing ones were very old dated. 
The administrators were unkind and the classrooms were very crowded. The teachers do not have enough spaces in the schools to develop themselves. The teachers' rooms are very crowded and many of the teachers are heavy smokers, smoking in the teachers' room. The facilities for the academic achievements such as laboratories, libraries, sports hall and others even not existing or there are a few in some schools. The recruitment is another obstacle for the high school students. They are anxious about their appointment to a school after they graduate. There is a common sense that if one has a social power can achieve the recruitment as well. In addition to all these obstacles, the main and most important perception of the students towards teaching profession is that teaching is not supported career in the society. As a social rank, teaching profession is at the bottom among the other professions. A considerable amount of students said that they would prefer to be a taxi driver rather than being a teacher. Interestingly, some of the teachers do taxi driving as a second job, due to not sufficient enough payment that they are worth. This strong majority of the students believe that teaching is neither a respected profession in the Kurdish society nor a rewarding job. However, very few students are willing to consider that teaching is rewarding and offers opportunities to bring positive change to society. Some of the students indicated that the policy makers are trying to overcome the barriers in front of being a teaching profession and education overall. However, low income, lack of resources and distribution of these resources are obstacles that the government should solve. Many other students indicated that the teachers should be paid enough and teaching profession should be promoted so that the education premises in Kurdistan could be a perfect starting point for developing the society in all fields.

\section{Discussion}

The main idea of this study was to demonstrate the attitudes of high school students, who are preparing for the university entrance examinations, towards teaching profession as a career choice in Kurdistan Region of Iraq. In addition to the main idea of this study, it was also aimed to measure how some different variables such as gender difference, family social background, ethnicity, school type and place they live responded to this study. Choosing a teaching profession to improve the education level, or to develop the society through education in Kurdistan is a chronic issue and it is not a small task. This is not a new problem; since Kurdistan got its autonomous government in 1991, there have been persistent shortages in traditional high demands of teaching career. This is mainly because the economical and political uncertainty of the region. Besides, when considering the data from the students survey it is recognized that there is a big indecision among the students towards teaching profession. The problem is, many of the students (45 percent) like teaching profession and 40 percent of them thought to be teacher as a career, but interestingly those who like teaching professionand thought to be a teacher do not want to be a teacher.One of the biggest reasons for this dilemma is that there is a lack of respect in the society. Since there have been a lack of social status respect to the teachers in Kurdistan society, the participants rate their judgments regarding the teaching profession is not respected and not a high status job. Consequently, this negative pressure effects students' career choice in their lives. In addition, Kurdistan region is in an ambiguous economical situation and the government is having difficulties in distributing the very limited sources. People are suffering because of the crises and couldn't get their salaries regularly and fully. Within this economical situation, even if the teachers would get a high salary regularly the participants indicated that they do not prefer to be a teacher. Students are looking for social status at first because social status is one of the influential factors while choosing a career (Watt \& Paul, 2007).

Interestingly, the participants' answers to the negative questions which try to understand the students assumptions towards teaching profession in love factors show that the students really think that teaching is an honorable profession that has to be done. However, the corruption of educational system affected students' decisions in decision-making.

Another important finding based on the empirical study is that high school students think that teaching is so stressful and there is over workload in the profession. According to Teacher workload research report conducted by Higton, Leonardi, Richards, \& Choudhoury, (2017) the majority of the respondents stated that workload in their schools are a fairly serious problem. Moreover, three-quarters of staff were dissatisfied with number of hours they usually work. The situation is the same as in Kurdistan. In an interview with the general director of the planning in Ministry of Education (Surchi, 2016) indicated that teachers were doing an over loaded work in the schools. One of the main reasons the students do not choose teaching as a career is work overload, and many of the teachers are burn out. 
Another surprising findings is the recritement of the teachers after they graduate from the universities. Here in Kurdistan Region, people really fond of to work and live in their hometowns. This is one of the most important situation in people's lives. A person from Slemani, Duhok or Erbil has to work in their cities. If anyone from Erbil is recruited to Slemani or vice-versa, it is a punishment or an exile to that person. The students were asked even if they would work in their home towns after they graduate in teacher training, most of them again did not prefer to choose teaching profession. This factor is as important as salary while choosing a job career in their lives, but even this factor did not convince them to be a teacher.

Another notably fact that the society and families, parents do not encouarge students to take up teaching as a career. The high schools students are really influenced by their friends, teachers, families and society's assumptions while choosing a career.

It was noticed during the open ended questions that most of the students who wanted to be teachers regardless of its problems, came from poor lower educated families who live in the villages or small towns. From the openended questions, it can be concluded that the students who wanted to be teachers come from generally poor middle class and crowded families. It is because of that, the economical situations the families face, forces them not to send their children to far and big cities to attend a university, as life standards are competitively higher compared to their hometowns. It is easier to meet the students' needs when they study in relatively low standard departments in which teaching profession is included. These results prove that teaching profession is for lower middle classes (Balyer \& Özcan, 2014;Banks, 1995; Zeichner, 1996). Besides, the students who are coming from the crowded families choose teaching as a career just because of the extrinsic reasons.

In the salary and working with children factors, there is a big difference in the responses in terms of gender. In other words, while male students prefer salary, the female students prefer working with children. In this respect, it can be concluded that female students choose teaching profession as career with intrinsic and altruistic motives. The female students dominantly indicated that they love working with the children and they are seen more committed. This result is also consistent with many others done previously (Butcher \& Lewis, 2002; Johnston, McKeown, \& McEwen, 1999; Hutchison \& Johnson, 1994). This result might be a proove that teaching is perceived as a feminized profession in Kurdistan.

From the open ended interviews,another result can be obtained in regards to scholorship. There aren't any scholorship programs or organizations in Kurdistan Region. Neither the Government nor the private institutions provide scholorships to the students. However, four years ago, an educational instution declared that they would give scholorship to the students who choose teaching as a career. in other words, that instution provides bursaries to the teacher candidates with some conditions. Many of the students pointed out that they could choose the teaching profession as a career because their low financial circumstances. As a result five hundred students are studying teaching training with bursary at a private university in the region. Many of those students who are studying with the bursaries now say that, as a result of councelling and guidance, teaching is a committed job to look after the good and sound, to show ideals, and to direct the students in the face of new developments and calamities.

In this research study, it was clearly found that a great deal of participants consider teaching as a sacred duty. It is because the perception of teaching from the religious and historical perspectives. From this assumption, the students pointed out that their most crucial aim is to develop the society by activating their inert energy and with $\mathrm{t}$; make them walk towards their historical ideal. In such a mobilization, it would be an utmost necessity to raise people from all walks of life - the intellectual, the artisan, the peasant, the city-dweller, the student, the teacher, the preacher, etc.- on common denominators that can elevate their country to a position where it can act in a balancing role among other world states; and nourishing their society with the understanding that love for truth and the desire for learning and research can be the means to rise to the Divine through education, as a result, with the quality and committed teachers.

\section{Conclusion}

The majority of the students who are studying at $12^{\text {th }}$ grade in high schools in different parts of Kurdistan Region of Iraq do not intend to study the teaching profession at the universities. For many of the students teaching is a low status job in the eyes of society and their families. The salary and frequency of payment is not regular and this makes the teaching profession very uninterested. 
Although students think and believe that education is the only way to raise a new notion and bring up the societies, they are reluctant to be teachers and take part in the education field. It not because of they do not like teaching, it is because of the economical and political uncertainty of the region. It is worth to say from the qualitative and quantitative result is that the participants see the teaching profession with an over loaded job, both in and outside the school. The results also show that teaching is a low-level status job, which means students from the middle class choose the teaching as a profession. On the other hand, female students choose from the intrinsic motives hence male students choose their careers based on extrinsic factors. Another important result from the study is that those participants are encouraged neither by the society nor by the families and friend to choose the teaching as a profession. One of the other most important findings from this study is that teaching profession can be a brilliant option in choosing career for the individuals' future on condition that the obstacles in front of the profession should be cleared up. Although majority of the students think that teaching profession is a blessed duty, extrinsic, extrinsic and altruistic factors play an important role while choosing the teaching profession as a career.

\section{Recommendation}

This mixed method research study tried to examine the high school students' attitudes towards teaching profession and how best policies can be made to increase the popularity of the teaching profession ensuring all students to be well respected teachers in the society. In this respect some recommendations have been reached through the results in this study:

- The first is a paradigm shift: As the students believe that education is the only lasting solution for society's problems and the needs of humanity, there should be a new appreciation for the enterprise of education and the profession of teaching, elevating both to a noble status.

- The incomes of the teachers should be improved in line with other professions like medicine, engineer and bureaucracy

- The over workload issues should be decreased to manageable situation. The over workload ends with a stress and unsuccessfulness.

- Teachers are needed to be supported and respected by the society and should be seen as a noble status. The media can portray teaching as a blessed and ideal profession and must refrain from negative reporting.

- The teacher candidates should be supported with the accommodation, food, loans or bursaries, because many of the poor students cannot pursue their education or they even do not go to the universities.

- The curriculum for the high schools should be revised and courses should put in the curriculum regarding the altruism or the elimination of selfishness and establishment of community service spirit in the field of education.

- A policy should be made to bring together the educator, the parent, and the sponsor in a tripartite relationship for the altruistic service of humanity through education.

\section{References}

Alberts, C., Mbalo, N. F., \& Ackermann, C. J. (2003). Adolescents' perceptions of the relevance of domains of identity formation: A South African cross-cultural study. Journal Youth and Adolescence,, 32 (3), pp. 169-184.

Balyer, A., \& Özcan, K. (2014). Choosing teaching profession as a career: Students' reasons. International Education Studies, 75 (5), pp. 104-115.

Banks, J. A. (1995). Multicultural education: Historical development, dimensions, and practice. In J. A. Banks, \& C. Banks, Handbook of Research on Multicultural Education. New York: Simon and Schuster Macmillan.

Brown, M. N. (1992). Carribean first-year teachers' reasons for choosing teaching as a career,. Journal of Education for Teaching,, 18, pp. 185-195.

Butcher, J., \& Lewis, E. (2002). Why not teaching? Senior students have their say. Australian Association for Research in Education Conference. Brisbane.

Chisholm, L. (1999). The Democratization of Schools and politics of Teacher's Work in South Africa. Compare, 29 (2), pp. 111-126. 
Chuene, K., Lubben, F., \& Newson, G. (1999). The views of pre-service and novice teachers on mathematics teaching in South Africa related to their educational experience. Educational Research, 41, pp. 23-34.

Farmer, H. (1995). Gender Differences in Adoloscent Carrer Exploration. Greensbro, NC.

Gottfredson, L. (1981). Circumscription and compromise: A developmental theorry of occupational aspirations. Journal of Councelling Psychology, 28 (6), pp. 545-579.

Gough, N. (1990). Challenges of Change: Myths of the Near Future in Australian Education. Australian Teacher Education Association. Adelaide.

Güneyli, A., \& Aslan, C. (2009). Evaluation of Turkish prospective teachers' attitudes towardst eaching profession (Near East University case). Procedia-Social and Behavioral Sciences, 1(1), 313-319.

Hall, D., \& Langton, B. (2006). Perceptions of the Status of Teachers. Retrieved April 15, 2018, from https://educationcouncil.org.nz/sites/default/files/Perceptions\%20of\%

20the\%20Status\%20of\%20Teachers\%20-\%202006.pdf

Halperin, R., \& Ratteree, B. (2003). Where have all the teachers gone? The silent crisis. Prospects, XXXIII (2), pp. 133-138.

Herring, R. (1998). Career Councelling in Schools: Multicultural and Developmental Perspectives. Alexandria, VA: American Councelling Association .

Higton, J., Leonardi, S., Richards, N., \& Choudhoury, A. (2017). Teacher Workload Survey. University of Warwick, Institute for Employment Research. Coventry: University of Warwick Publishing.

Hutchison, G., \& Johnson, B. (1994). Teaching as a career: examining high school students' perspectives. Action in Teacher Education, 15 (4), pp. 61-67.

Johnston, J., McKeown, E., \& McEwen, A. (1999). Primary teaching as a career choice: The views of male and female sixth-form students. Research Papers in Education, 142 (2), pp. 181-197.

Kyriacou, C., \& Coulthard, M. (2000). Undergraduates' Views of Teaching as a Career Choice. Journal of Education for Teaching: International research and pedagogy, 26 (2), pp. 117-126.

Kyriacou, C., \& Kobori, M. (1998). Motivation to learn and teach English in Slovenia. Educational Studies,, 24, pp. 345-352.

Krumboltz, J. D. (1983). Private rules in career decision-making. National Center for Research in Vocational Education. The Ohio State University.

McDonald, J. L., \& Jessell, J. C. (1992). Influence of selected variables on occupational attitudes and perceived occupational abilities of young adolescents. Journal of Career Development, 18, pp. 239-250.

Murnane, R. J., Singer, J. D., Willett, J. B., Kemple, J. J., \& Olsen, R. J. (1991). Who will teach? Policies that matter. Cambridge, MA: Harvard University Press.

Mutshaeni, H. N., Denhere, C., \& Ravhuhali, F. (2015). High School Students' Attitudes towards the Teaching Profession. Journal of Sociology and Social Anthropology, 6 (2), pp. 227-233.

Surchi, Y. (2016). School needs in Kurdstan. (S. Celik, Interviewer)

Watt, H. M., \& Paul, R. W. (2007). Motivational Factors Influencing Teaching as a Career Choice: Development and Validation of the FIT-Choice Scale,. The Journal of Experimental Education, 75 (3), pp. 167-202.

Zeichner, K. (1996). Educating teachers for cultural diversity. In K. Zeichner, S.

Melnick, \& M. Gomez, Currents of reform in preservice teacher education. New York: Teachers College Press. 